\title{
Analysis of the Main Cause for the Entrepreneurs Drop Out in Micro and Small Enterprises: Evidences from Nekemte Town, Eastern Wollega Zone, Oromia Regional State, Ethiopia
}

Amenu Daba Waktola ${ }^{1 *}$ and Merga Atnafu Hirpha ${ }^{2}$

${ }^{1}$ Department of Economics, Wollega University, P.O Box.395, Nekemte, Ethiopia

${ }^{2}$ Shambu Branch, Commercial bank of Ethiopia, Shambu, Ethiopia

\begin{abstract}
In Ethiopia, Micro and small enterprises (MSE) are recognized as important vehicles of economic growth, employment creation, and income generation. As a result, MSE occupy a prominent position in the development agenda of Ethiopia. The main objective of this study is to examine and analysis different major factors that cause for entrepreneur's dropout from MSE business in Nekemte town. The total population of the study was 3,070 MSEs operating in five sectors (construction, manufacturing, urban agriculture, trade and service) which is used as a stratum. Proportional stratified sampling technique was used for the selection of 172 MSEs from the strata. Only primary data was employed and it was collected by using structured questionnaire from the selected respondents. The study shows that that $58.7 \%$ of entrepreneurs face members drop out from their business whereas the remaining of them does not. From the descriptive statistics analysis the study finding show that the most contributing factor for members drop out from the business has three dimensions. First, individual dimensional factor (like lack of need for achievement of the business and risk taking propensity of members, personal background and individual competence are the most in decreasing order). Second, business dimensional factor(the most serious factor that contributes for entrepreneur drop out from MSE business is slow growth of the business followed by supply and demand related factors) and the third external business environmental factors(are lack of work premises followed by access to credit, and tax system, societal attitude towards MSE product/services in decreasing order). The econometric analysis reveals that 10 of the 18 variables used for the binary logistic regression analysis are highly influential over the drop out of entrepreneurs from their business. The 10 significantly contributing factors are at 1 and $5 \%$ level of significance are sex of the entrepreneurs; age of the entrepreneurs; educational status; sector of the business; source of finance; form of the business; possessing business plan; existence of sufficient market for the product/services; networking capacity of the entrepreneurs; and corruption from MSE support institutions. The multivariate regression results shows that individual dimensional affects positively the drop out of entrepreneurs from MSE business significantly at one percent level of significance indicating that individual dimensional factors contribute the most to the drop out of entrepreneurs from their business in the study area.
\end{abstract}

Keywords: Binary logit; Micro and small enterprise; Entrepreneurs

\section{Introduction}

For many years, Micro and Small Enterprises (MSEs) has been a significant feature of certain economies. Now days, in almost all economies of the world especially in developing countries, MSEs are crucial and are a key factor for sustained growth and development. They are the lifeblood of most economies [1]. MSEs have a tremendous potential in generating employment for the majority of the urban labor force. They are also important sources of income not only for those people who could not find employment in other sectors but also provide cushion to falling incomes of low wage earners [2].

MSEs have been particularly responsive to flexible production of different products and absorbing of labour forces being the most dynamic at creating opportunities for workers to engage in productive activity and generating more job opportunities than large enterprises, particularly in non-agricultural employment. Today MSEs often represent a majority of all enterprises and have the potential to employ a significant proportion of the world's workers.

Urbanization, with its challenges and opportunities has become a development agenda of developing countries, especially after the nineties. In almost all developing countries, the rate of urbanization is, by far, exceeding the population growth rate of their national average, indicating rural-urban migration as a major factor for such an explosion of which about $90 \%$ of migrants join the urban informal sector. In Ethiopia, in 2009 the growth rate of urbanization at about 4\% while that of national population growth was about $2.7 \%$ [3].

During the last decade, Ethiopia has seen significant urban growth as the number of cities with 50,000 people has grown. The rapid urbanization and population growth have outpaced the country's ability to create jobs. In the meantime, the private sector, which is concentrated within and around those large towns, consists of micro and small enterprises. Currently, there are clear indications that MSE are flourishing across the country. In Ethiopia, MSE sector becomes the second largest employment generating sector for the poor households following the agriculture sector [4].

According to the Central Statistical Agency [5], almost 50\% jobs

*Corresponding author: Amenu Daba Waktola, Department of Economics Wollega University, P.O Box.395, Nekemte, Ethiopia, Tel: +251576617981; E-mail: dabaalwayswinner@gmail.com

Received October 03, 2016; Accepted November 02, 2016; Published November 04, 2016

Citation: Waktola AD, Hirpha MA (2016) Analysis of the Main Cause for the Entrepreneurs Drop Out in Micro and Small Enterprises: Evidences from Nekemte Town, Eastern Wollega Zone, Oromia Regional State, Ethiopia. Int J Econ Manag Sci 5: 376. doi: 10.4172/2162-6359.1000376

Copyright: (c) 2016 Waktola AD, et al. This is an open-access article distributed under the terms of the Creative Commons Attribution License, which permits unrestricted use, distribution, and reproduction in any medium, provided the original author and source are credited. 
created in Ethiopia are attributable to small business enterprises were 974,676 micro and 31,863 are small enterprises, which accounts for $99.40 \%$ and $0.46 \%$ respectively. Large and medium enterprises that hired more than ten employees were 642 accounting for the remaining $0.14 \%$. In addition, micro enterprises and small enterprises provide employment opportunities to $89.75 \%$ and $0.91 \%$ respectively. Large and medium enterprises on the other hand accounted for about 9.34 and 0.91percent of individual employment respectively [5].

There is a comprehensive support provided to MSEs. The rationale behind the support for the MSE sector Ethiopia is that the sector is given recognition in the country's Growth and Transformation Plan (GTP) in general and the industry development plan in particular considering the sector serves as vehicle of development and broadens employment opportunities at urban center. The elements of the sector are taken as the major productive forces in the manufacturing sector. MSEs serve as incubation hubs for developmental investors. MSEs play great role in utilizing local resources and are labor intensive [6]. As a result MSEs helped the enterprises to create temporary and permanent employment opportunities for over 1.6 million citizens within the first two years of the GTP period to accomplish $56 \%$ of the three million targets to be achieved by the end of 2014/2015.

Despite, several supports provided for MSE, members of MSE quit from their MSE in which they are organized. The reasons for membership discontinuation are multidimensional and complex. The ranges of reasons that cause for members' exit were diverse. This includes management problem among the MSE members; socioeconomic or health problem; the pre request of the saving to loan ratio; members' expectation of support from support institutions; retirement of individual and distance between individual home and their work premise. Sometimes members are given false hope to attract them to be a member. Attracted by the expectation many individuals gravitate to the MSE sector some of whom are not creditworthy but deserve direct employment or economic supports. Such members exit MSE after testing as they are getting no such support from the support institutions.

Particular perspectives drive most of the MSE studies. Understanding small business however, requires analysis from various dimensions since success or failure of a business is a complex process that comes because of a number of factors difficult to describe by a single perspective or dimension [7]. For instance, according to the inventory conducted in June 2014 on MSEs by Nekemte town MSE development agency, there are 3,300 MSEs with 14,760 entrepreneurs in the town. Of this figure, 230 MSEs are completely dissolved whereas 1524 MSE are operating with their full members. Above $46.8 \%$ of MSEs $(1,546)$ are operating with members with at least one entrepreneur dropped from the enterprise (Figure 1).

Nowadays MSEs are recognized as vehicles for economic growth and reduce poverty and unemployment [8]. They are generally regarded as the driving force of economic growth, job creation and poverty reduction in developing countries. MSEs are the means through which accelerated economic growth and rapid industrialization is to be realized.

Despite the fact that MSEs have been recognized as a major contemporary source of employment and income in a growing number of developing countries, yet relatively little is known and emphasized about the characteristics, growth and dropout of entrepreneurs from these enterprises. Also $98 \%$ of business firms are MSE out of which micro enterprises represent $65 \%$ of all businesses. The fact that the majority of enterprises are MSEs indicates that established enterprises find it difficult to grow to the next stages of middle and large scale industries [9].

According to the study conducted by Pagura et al. poor business performance was a leading case for members drop out. Members left due to inconsistent and business stoppages and/or total business failures. Another major reason for members exit was due to personal problem. This includes migration, sickness or death as well as family disapproval on frequently appearing on members meeting. Weather related problem was also another contributing factor for individual drop outs.

More over studies conducted so far concluded that the major problem of MSEs are access to working capital, inadequate infrastructure, high transactional cost, limited managerial and technical experts and market related issues. MSE owners were offered less assistance for further expansion once they were established as small enterprises and they face constraints such as lack of financing, access to land/business premises, burdensome tax, market saturation, competition from the informal sector are the major constraints that leads to dropout from their organization.

Study conducted by Zemenu and Mohammed shows that most of

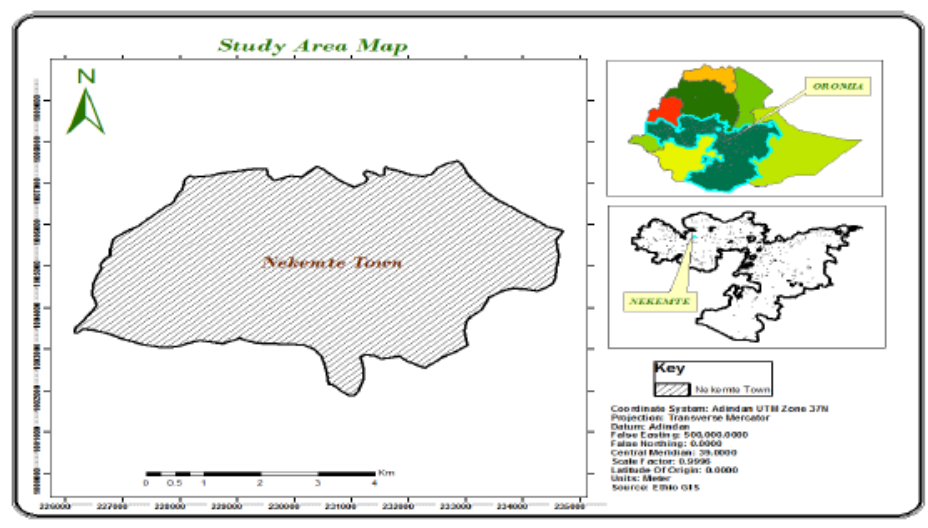

Figure 1: Description of the study area. 
Citation: Waktola AD, Hirpha MA (2016) Analysis of the Main Cause for the Entrepreneurs Drop Out in Micro and Small Enterprises: Evidences from Nekemte Town, Eastern Wollega Zone, Oromia Regional State, Ethiopia. Int J Econ Manag Sci 5: 376. doi: 10.4172/2162-6359.1000376

the dissolved MSE businesses contributed to members drop out are trade sector and service. In fact the most unstable sectors are trade and service sectors than the manufacturing and construction sectors. The major reasons for dissolving of MSE's is bankrupts in their business, lack of working premise, formality, finance, address or sector change, asset sale, tax, natural factors, social factors, personal reasons and business loss.

Currently, it was observed that certain MSEs operating in Nekemte town administration are undergoing reform of their business from cooperative to partnership during the renewal of their work premises. This is due to the dropout of individuals from members of the MSE in the organization of cooperative that requires at least ten individuals to the one that request at least three individual to be organized as MSE. This was an indication for the existence of different factors that contributes for individual entrepreneurs' dropout from the MSE.

The study conducted on problems of micro and small enterprises in Addis Ababa in Kolfe, Kirkos and Yeka sub cities conclude that the number of entrepreneurs in all types of the enterprises is decreased almost by half amount. This was a serious problem particularly in cobble stone, textile and garment, food processing and urban agriculture. The researcher described the main factors that facilitated high dropout of members include weak institutional support, lack of commitment from the members, lack of market place, poor location, lack of appropriate raw materials, absence of price arrangement by the government and lack of infrastructure. However, Researcher was not planned to see the drop out of members for the study in the hypothesis, research question and objectives. The investigator was tried to show the level of drop out in each sector of the enterprise and discusses the main cause for the drop out of entrepreneurs. However, there is no any data whether the justification the researcher described was supported by results obtained from the respondents like the dropout rate. Moreover, none of the investigators' research tool gives an indication for the reason for members drop out from their MSE leading to subjective judgment by the researcher.

Thus, this study assesses these factors that are contributing for entrepreneur's dropout from their MSEs so as to achieve their contributions in employment and economic growth by overcoming a series of constraints they are facing. Thus, this study is aimed at assessment of factors causing individual members drop out from micro and small enterprises in Nekemte town. Hence, the objective of this study is to identify the contributing factors of entrepreneurs' dropout from MSEs. To assess factors causing individual entrepreneurs drop out from micro and small enterprises in Nekemte town administration. Assess the magnitude of drop out of entrepreneurs from MSE across the five sub-sectors in Nekemte town administration; identify internal factors (entrepreneurial skills potential organizational structures), and external factors (environmental factors) contributing for entrepreneurs drop out from MSEs in the study area.

\section{Research Methodology}

\section{Description of the study area}

Nekemte town is located at $327 \mathrm{~km}$ from Addis Ababa. The town was founded in 1865E.C as a small village under the auspices of King Moroda Bakare. The word Nekemte was derived from the owner of the land whose name was "Nekemte Gada Otaa" who had lived for a long time at this specific place. Initially it was serving as a center of trade root; by the name "sarara" trade exchanged their product like ivory, gold, silver, and different types of grain from Maji and Kafa to Mituwa,
Gondor and Gojam. The town has an altitudinal range of 1,960 to 2,170 meter above sea level and its temperature range is $140 \mathrm{C}$ to $260 \mathrm{C}$ and its annual rain fall is between 1500 to $2200 \mathrm{~mm}$. It is medium size town and one of the first grades of 20 cities of Oromia. Nekemte is surrounded by Guto Gida in the north, Wayu Tuka in the east, Guto Gida in the west and south (Table 1).

When the educational background of the respondents is considered, it ranges from below high school to first degree. The study shows that $47(27.3 \%)$ of the respondents are below high school that can read and write whereas $43(25.0 \%)$ of the respondents were high school complete. The result of the study also shows that $41(23.8 \%)$ of the entrepreneurs are TVET graduates. The remaining $21(12.2 \%)$ have college diploma and $20(11.6 \%)$ of the entrepreneurs are first degree holders. When the cumulative effect of the educational level of the respondents is considered, the study reveals that $90(52.3 \%)$ of the respondents are high school complete and below. Also, 152 (88.4\%) of the entrepreneurs are operating their business with an educational achievement of Diploma and below. Schooling is important personal background that influences MSE performance and growth. Education helps entrepreneurs to make good judgments, best use of information, exploit opportunities well leading to firm growth and success. The result of this study argues that having lower education achievements and attending TVET training significantly influenced the likelihood of being entrepreneurs rather than wage employees in the study area. As a result of the above importance of schooling, entrepreneurs with lower educational achievements may leave their business due to lack of such backgrounds.

When the marital status of the respondents are considered, the result of the study shows that $113(65.7 \%)$ of the entrepreneurs are married whereas $52(30.2 \%)$ of them are single entrepreneurs. The remaining 7 (4.1\%) of the respondents are those who are divorced. The study result shows that majority of the entrepreneurs are those who have additional burden of family case that probably share their business time for family caring in the study area. Despite the fact that marriage is one important value of culture in the region, the large percentage of married entrepreneurs could be also explained as they fulfill the

\begin{tabular}{|c|c|c|}
\hline Characteristic & Variable & $\begin{array}{c}\text { Frequency } \\
\text { (percentage) }\end{array}$ \\
\hline \multirow{2}{*}{ Sex of the respondent } & Male & $104(60.5 \%)$ \\
\hline & Female & $68(39.5 \%)$ \\
\hline \multirow{3}{*}{ Age of the respondent } & 15 to 29 years & $91(52.9 \%)$ \\
\hline & $30-45$ years & $73(42.4 \%)$ \\
\hline & $46-60$ years & $8(4.7 \%)$ \\
\hline \multirow{5}{*}{ Educational status of the respondents } & Below high school & $47(27.3 \%)$ \\
\hline & High school complete & $43(25.0 \%)$ \\
\hline & TVET graduate & $41(23.8 \%)$ \\
\hline & College diploma & $21(12.2 \%)$ \\
\hline & First degree & $2011.6 \%)$ \\
\hline \multirow{3}{*}{ Marital status of the respondents } & Married & $113(65.7 \%)$ \\
\hline & Single & $52(30.2 \%)$ \\
\hline & Divorced & $7(4.1 \%)$ \\
\hline \multirow{6}{*}{$\begin{array}{l}\text { Sub-city of the respondent where } \\
\text { they are operating }\end{array}$} & Chalalaki & $36(20.9 \%)$ \\
\hline & Burka Jato & $25(14.5 \%)$ \\
\hline & Bakanisa Kase & $34(19.8 \%)$ \\
\hline & Kaso & $28(16.3 \%)$ \\
\hline & Bake Jama & $17(9.9 \%)$ \\
\hline & Darge & $32(18.6 \%)$ \\
\hline
\end{tabular}

Source: Own survey, 2015

Table 1: Demographic characteristics of the entrepreneurs. 
Citation: Waktola AD, Hirpha MA (2016) Analysis of the Main Cause for the Entrepreneurs Drop Out in Micro and Small Enterprises: Evidences from Nekemte Town, Eastern Wollega Zone, Oromia Regional State, Ethiopia. Int J Econ Manag Sci 5: 376. doi: 10.4172/2162-6359.1000376

Page 4 of 16

basic marriage needs (feeding, clothing, and schooling of children). Both husbands and wives have to contribute to the family income for home consumption. The contribution of the business income to home consumption affects business performance that in turn makes the decline in the profitability of the business leading members' dropout.

Finally, all of the sample respondents in the survey are from the six sub-city of the town. The study shows that $36(20.9 \%)$ of the respondents are operating in Chalalaki followed by $34(19.8 \%)$ of the entrepreneurs operating in Bakanisa Kase. It also shows that 32 (18.6\%) of the entrepreneurs are from Darge with lowest operators for the study being from Bake Jama that accounts only 17 (9.9\%) of the entrepreneurs. The sizes of the respondents are proportional to that of the active MSE operating in each of the sub-cities. This normal distribution of the respondents in each sub-city gives the researcher confidentiality to assess factors that contribute member's dropout across each of the sub-cities. Each of the sub-city from which the survey conducted does not have the same access to market and potential customers for MSE product or services. Thus, situational problem related to business location can cause MSE members to drop from their business due to different socio-economic factors of their surroundings.

Individual entrepreneurs characteristics of the respondents: Most of the prevalent areas in which MSE faces a problem are sales or marketing, human resource management, and general marketing research and training that are related to individual entrepreneurial characteristics. The structure of MSE business organization is composed of manager, accountant/secretary, cashier and members positions. All owner members of an enterprise do not have the same position and power in MSE business. The study shows that 128 (74.4\%) of the respondents are working on the managerial position followed by cashier that accounts 32 (13.4\%) indicating few number of members that works without any position as member only that accounts for 11 (6.4\%) in the sample survey. The remaining 10 (5.8\%) of respondents are the one that are working on the position of an accountant in the business.

The analysis of the result of the study implies that $93.6 \%$ of the respondents have a position that helps in decision making of the business operation. It is also described that $52.3 \%$ of the respondents are with educational achievements of high school complete and below high school that can read and write. This indicates MSE with low level of educational achievements are becoming working on the managerial position who are incapable of understanding the modern business environment that intern affects the growth and profitability of MSEs. This in turn leads to the MSE members not to be cope up with the changing environment and leads to the dropout from their business due to inefficiency in the prevailing market competition of the business they are operating.

In relation to work experience of the respondent, the study result reveals that most of the respondents 123 (71.5\%) have work experience on the sector they have organized in and only 49 (28.5\%) of the respondents are reported that they have no work experience on which they had organized. The growth or failure of a firm is, to a certain extent, a matter of decisions made by individual entrepreneur. This is very much pronounced for MSEs that are run by owner-managers. The study result reveals that $149(86.6 \%)$ of the respondents reported that they have the required managerial skill that helps them to manage the day to day operation of a business whereas the remaining $23(13.4 \%)$ of the respondents reported that they lack managerial skill required for the management of the enterprise business (Table 2).

\begin{tabular}{|c|c|c|}
\hline \multirow[t]{4}{*}{ Position of the respondent in the MSE } & Manager & $128(74.4 \%)$ \\
\hline & Accountant & $10(5.8 \%)$ \\
\hline & Cashier & $32(13.4 \%)$ \\
\hline & Member & $11(6.4 \%)$ \\
\hline \multirow[t]{2}{*}{ Work experience of the respondents at start ups } & Yes & $123(71.5 \%)$ \\
\hline & No & $49(28.5 \%)$ \\
\hline \multirow[t]{2}{*}{ Managerial skill of the respondent } & Yes & $149(86.6 \%)$ \\
\hline & No & $23(13.4 \%)$ \\
\hline \multirow[t]{2}{*}{ Technical skill of the respondent } & Yes & $135(78.5 \%)$ \\
\hline & No & $37(21.5 \%)$ \\
\hline \multirow[t]{2}{*}{ Marketing skill of the respondents } & Yes & $144(83.7 \%)$ \\
\hline & No & $28(16.3 \%)$ \\
\hline \multirow{2}{*}{$\begin{array}{l}\text { Attending entrepreneurial training by } \\
\text { respondents }\end{array}$} & Yes & $77(44.8 \%)$ \\
\hline & No & $95(55.2 \%)$ \\
\hline \multirow[t]{2}{*}{ Having persistence of the respondents } & Yes & $154(89.5 \%)$ \\
\hline & No & $18(10.5 \%)$ \\
\hline \multirow[t]{2}{*}{ Risk taking capacity of the respondents } & Yes & $155(90.1 \%)$ \\
\hline & No & $17(9.9 \%)$ \\
\hline \multirow[t]{2}{*}{ Networking capacity of the respondents } & Yes & $87(50.6 \%)$ \\
\hline & No & $85(49.5 \%)$ \\
\hline \multirow[t]{2}{*}{ Economic orientation of the respondents } & Yes & $140(81.4 \%)$ \\
\hline & No & $32(18.6 \%)$ \\
\hline
\end{tabular}

Source: Own survey, 2015.

Table 2: Individual entrepreneurial characteristics of the respondent.

The technical skill in small enterprise is the system that helps in the operation of a business by MSE members. From the operations point of view it is the most important skill that determines success or failure of the business and that in turn affects the retention and drop out of members from the MSE business. The result of the study shows that $135(78.5 \%)$ of the respondents reported that they have the required technical skill for the operation of the business whereas the remaining $37(21.5 \%)$ of the respondents reported that they lack the required technical skill for the operation of their business.

The marketing skill is another type of individual entrepreneur skill that is crucial for firm growth or failure. Firm that shows a high growth trend may retain member than firm that stagnant and forces members to leave the business in case of failure by push factor. The study result reveals that majority of the respondents, 144 (83.7\%), of the respondents reported that they have the required marketing skill. It is only $28(16.3 \%)$ of the respondents that are reported as they lack marketing skill in their business. The marketing problem has been widely acknowledged as being the most important of all activities and critical for the survival and growth of MSEs.

However, many studies found owner/managers of MSEs as having a very limited understanding of the marketing concept generally to be little more than advertising and public relations and lacking adequate marketing skills. Specifically, problems in promotion and marketing research were frequently encountered by MSEs. These problems include the selection of promotional media, low purchasing power of customers, advertising, content design and format of the promotional materials, market size, location and addresses of potential customers. The low level of understanding of the marketing concepts probably leads to poor performance that leads to drop out members from their MSE business.

An individual competency is defined as the knowledge, skills and abilities required to perform a given task [10]. Individual competencies are improved through an entrepreneurial training provision for the MSE members. The result of the study reveals that 77 (44.8\%) of the 
Citation: Waktola AD, Hirpha MA (2016) Analysis of the Main Cause for the Entrepreneurs Drop Out in Micro and Small Enterprises: Evidences from Nekemte Town, Eastern Wollega Zone, Oromia Regional State, Ethiopia. Int J Econ Manag Sci 5: 376. doi: 10.4172/2162-6359.1000376

Page 5 of 16

respondents are attended entrepreneurial training whereas $95(55.2 \%)$ of them did not. Lack of entrepreneurial training by the members of the MSE business may contribute for the drop out of members from their business.

Another entrepreneurial behavior that helps MSE business success is the persistence and commitment level of the entrepreneurs in the business. The result of the study shows that $154(89.5 \%)$ of the respondents reported that they have strong persistence in the activity they are operating whereas the remaining 18 (10.5\%) does not have the required persistence behavior in the operation and related activities. The level of commitment of the members for the success of their business also varies among the members. The result of the study reveals that $152988.4 \%$ ) of the respondents reported that they have strong commitment for the attainment of the business goal whereas $20(11.6 \%)$ of the respondents were not. Lack of strong persistence and commitment may lead to the drop out of members from their business in the study area.

When we consider the risk taking traits of the respondent, the result of the study reveals that majority of the respondents 155 (90.1\%) of them are reported as they can take risks related to their business whereas the remaining 17 (9.9\%) of them are reported as they were risk averse entrepreneurs. Openness to risk taking is an important trait of the entrepreneur especially in Africa where entrepreneurs face uncertainties with regard to prices, demand, reliability of infrastructure and corruption. Traditionally, female generated funds are used to cover family's basic needs; female entrepreneurs tend to avoid taking risks that may help firm expansion.

Networking capacity of the entrepreneurs is the mail individual behavior that helps in the increasing the sales volume as well as customer attraction for the business. The result of the study reveals that it is only half the respondents, 87 (50.6\%) of the respondents that have networking capacity for their business whereas the remaining 85 (49.4 $\%)$ of the respondents reported that they lack networking capacity for the expansion and growth of their business. Lack of such critical business behavior by the members may leads to the drop out members of MSE from the business in the study area.

Economic behavior is somewhat automatic in nature and more likely to be standardized due to the fact that entrepreneurship consists of doing new things in a new manner. Economic orientation is the main motive that drives entrepreneurial activities among the respondents. The result of the study shows that $140(81.4 \%)$ of the respondents reported that they have economic orientation whereas the remaining $32(18.6 \%)$ of them did not have economic orientation of the business. The lack of economic orientation by the entrepreneurs may lead to members drop out from their business in the study area.

Business/Organizational characterization of the respondents: As shown in Table 3, entrepreneurial activities are developed from the five economic sectors namely: industry; service; construction; agriculture; and trade sectors. The result of the study shows that majority of the respondents $75(43.6 \%)$ are from the service sector that are involved in pressing, hotel, computer centers, coffee house, mini restaurants and others followed by trade 45 (26.2\%) that perform purchase and resale of different commodities. Respondents from the indusial sector that are involved in metal work, wood industries that transforms wood to semi or final product such as house furnishing accounts for 29 (16.9\%). The number of involvement of the construction sector entrepreneurs is $12(7.0 \%)$ with the lowest number of respondents from main stay of the country, agriculture accounts $11(6.4 \%)$ respondents. Agriculture

\begin{tabular}{|c|c|c|}
\hline Characteristic & Variable & $\begin{array}{c}\text { Frequency } \\
\text { (percentage) }\end{array}$ \\
\hline \multirow{5}{*}{$\begin{array}{l}\text { Sector of the MSE in which the respondents } \\
\text { are operating }\end{array}$} & Industry & $29(16.9 \%)$ \\
\hline & Service & $75(43.6 \%)$ \\
\hline & Construction & $12(7.0 \%)$ \\
\hline & Agriculture & $11(6.4 \%)$ \\
\hline & Trade & $45(26.2 \%)$ \\
\hline \multirow[t]{2}{*}{ Legal form of the MSE business } & Partnership & $127(73.9 \%)$ \\
\hline & Cooperative & $45(26.2 \%)$ \\
\hline \multirow[t]{2}{*}{ Possessing of business license by the MSE } & Yes & $147(85.5 \%)$ \\
\hline & No & $25(14.5 \%)$ \\
\hline \multirow[t]{2}{*}{ Possession of business plan by the MSE } & Yes & $43(25.0 \%)$ \\
\hline & No & $129(75.0 \%)$ \\
\hline \multirow[t]{2}{*}{ Accounting and record keeping by MSE } & Yes & $74(43.0 \%)$ \\
\hline & No & $98(57.0 \%)$ \\
\hline Whether the MSE business is & Yes & $144(83.7 \%)$ \\
\hline Profitable or not & No & $28(16.3 \%)$ \\
\hline \multirow[t]{4}{*}{ Source of finance for the MSE business } & Personal saving & $91(52.9 \%)$ \\
\hline & $\begin{array}{c}\text { Borrowed from } \\
\text { MFI }\end{array}$ & $39(22.7 \%)$ \\
\hline & $\begin{array}{l}\text { Borrowed from } \\
\text { relatives }\end{array}$ & $23(13.4 \%)$ \\
\hline & Loan from NGOs & $19(11.0 \%)$ \\
\hline
\end{tabular}

Source: Own survey, 2015.

Table 3: Organization related determinants of entrepreneurs drop out.

which is an important component of economic development of the region is less represented in this survey. This could be explained by the fact that the survey was carried out largely in the urban areas where jobless people are more willing to undertake small business activities than farming and livestock rearing which are abandoned to peasants in the rural areas. Efficient programs capable to stimulate the jobless to undertake agricultural activities that could be a pillar of economic development in the region are required.

Concerning legal framework which is the administrative procedures; the official procedures required procedures for an enterprise creation; the deadline to accomplish a procedure, the cost of the procedure institutionalization sets the payment of minimum capital during the registration; appear to be long, complex, and costly at the local government structures that applies the organizing and licensing procedures. The result of the study shows that majority of the respondents, $127(73.9 \%)$ of the respondents are organized as partnership types of organization that requires 3 up to 9 members to be organized under one enterprise of the MSE business whereas the remaining 45 (26.2\%) of the entrepreneurs are those that are organized by the cooperative law of the rule and regulation of the country that requires at least 10 members to be organized in to one enterprise. The study also reveals that while $147(85.5 \%)$ of the respondents possess renewed business license for the business they run, the remaining $25(14.5 \%)$ does not have renewed business license due to different reasons related to loan repayment, audit activity and other factors legal and regulatory factors.

The legal and regulatory system that calls for complex registration and licensing requirements demands tedious and costly reporting practices imposing heavy costs on MSEs and hence reduce their profitability of the business. Unpredictable government policies coupled with grand corruption, high taxation pose great threat to growth of MSEs. They are disincentive to increasing the size of business operations. These MSE which are operating with obsolete license are become groped in the informal sector. Theses operators when 
Citation: Waktola AD, Hirpha MA (2016) Analysis of the Main Cause for the Entrepreneurs Drop Out in Micro and Small Enterprises: Evidences from Nekemte Town, Eastern Wollega Zone, Oromia Regional State, Ethiopia. Int J Econ Manag Sci 5: 376. doi: 10.4172/2162-6359.1000376

pushed by the government sector to become formalize their business, they prefer to quit their business. To be more efficient, policies and programs that help to reduce the dominance of informal sector should be developed at the local government level in the study area.

The entrepreneurial skill of guiding the business by the business plan and maintaining of accounting record of the business operation plays a critical role for the overall management of the progress of the business that the MSE operates. But, the result of the study shows that three fourth of the entrepreneurial 129 (75.0\%) lack business plan for their business whereas only one fourth, 43 (25.0\%) of the respondents are guided by the business plan. Moreover, despite, MSEs operating in Ethiopia are not legally required to maintain books of account and records of their business, the study shows result that 74 (43.0\%) of the respondents reported that they are maintaining records of accounting, raw material and fixed asset inventory records. However, 98 (57.0\%) of the respondents reported that they do not maintain accounting record for their business transactions. Moreover, the result of the study shows $144(83.7 \%)$ of the respondents reported that their business is profitable whereas the remaining $28(16.3 \%)$ of the respondents reported their business is unable to generate profit. The absence of accounting record may forces tax authority to use MSEs' daily/monthly sales income to levy tax on MSE business. This may lead to subjective type of tax determination up on MSE due to lack of accounting record for the MSE business. This may adversely affect the profitability of the MSE business leading the members' dissatisfaction and quit from the business.

From the business dimension, the researcher tries to see the effect of finance which is one of the major resources in any business, and the result shows that 91 (52.9\%) of the respondents reported their MSE is started business by personal saving which was not sufficient enough for expansion and growth of the business whereas 39 (22.7\%) of the respondents reported that they are started business with loan borrowed from micro finance institutions (MFIs). The study result also shows that $23(13.4 \%)$ of the respondents started business with finance obtained from relatives whereas the remaining 19 (11.0\%) of the respondents reported that as they are running their business assistance obtained from nongovernmental organization. The result of the study shows that more than three forth of the respondents are running their business by finance obtain from other than formal financial institutions due to the fact that many of the MSE operators fall short of preparing detailed business plan and project proposal for loan processing as they are less educated leading the MSE operators in the study area facing difficulties in getting loan from micro finance institutions due to the cumbersome policy and procedure that the micro finance institutions. The result of the study was in line with the study of Cabral, Mata and Elston that describe lack of access to financial resources hinders firms from growing to their optimal size. The slow growth of firms leads to dissatisfaction of members that in turn leads cause the drop out from the business.

External business environmental characterization of the respondents: The task environment comprises environmental elements such as availability of business premises, its sufficiency and suitability, competitors, suppliers, customers, bureaucracy in registration and licensing and support provision for business enterprise. Access to working and sales premises are also the other challenges to MSEs operating in the country. The study result reveals that $134(77.9 \%)$ of the respondents reported that they have no any problem with respect to work premise whereas the remaining 38 (22.1\%) of the respondents reported as they lack work premises for their business.
Also, the study result shows that $113(65.7 \%)$ of the respondents reported that they pay rent for their work premises whereas the remaining $59(34.3 \%)$ of the respondents reported that they are not pay rent for their work premises. The magnitude of result of this study is almost the same as the study conducted by Ageba and Amha in Ethiopia that indicated lack of premise and land are major bottleneck for MSE in Ethiopia in which 25\% of sampled entrepreneurs reported that lack of business premises has adversely affected the growth and survival of their businesses. The amount rent for working premises can also affect the growth of MSE business that in turn also affect the level of profit to be re-invested in to the business operation. Lack of work premise and the high cost of rent can push members of the enterprise to leave their business.

When we see the size or sufficiency of the work premises of the MSE is considered, the result of the study reveals that 99 (57.6\%) of the respondents reported that the work preemies was sufficient for their business operation whereas 73 (42.4\%) of the respondent reported that they are unhappy with sufficient work premise. Similarly, the result of the study reveal that $114(66.3 \%)$ of the respondents reported that their work premises was found in suitable area whereas 58 (33.7\%) of the respondents reported that they are unhappy with the location of the work premises in which they are running their business. The location of MSE business could have a direct influence on profitability and growth of MSEs by affecting supply and demand conditions that have a direct implication on costs and benefits accruing for the business. Enterprises located at commercial districts may experience better demand for their product. MSEs operating in suitable locations and market locations were found to show a significant survival advantage compared to home based enterprises [11], 'Small firm dynamics: Evidence from Africa and Latin America, indicating that there is high chance of members drop out from home based operators than those who are operating in a suitable business location (Table 4 ).

When the market condition for the product and raw material is considered, the study result reveals that 108 (62.5\%) of the respondents have sufficient market for their product/services whereas the remaining $64(37.2 \%)$ of the respondents reported that they do not have sufficient market for their product/services. Similarly, the study result shows

\begin{tabular}{|l|c|c|}
\hline Characteristic & Variable & $\begin{array}{c}\text { Frequency } \\
\text { (percentage) }\end{array}$ \\
\hline Possessing of work premises by the MSE members & Yes & $134(77.9 \%)$ \\
\cline { 2 - 3 } & No & $38(22.1 \%)$ \\
\hline Sufficiency of the work premise in which the members & Yes & $99(57.6 \%)$ \\
\cline { 2 - 3 } operate & No & $73(42.4 \%)$ \\
\hline Suitability of the work premise in which the members & Yes & $114(66.3 \%)$ \\
\cline { 2 - 3 } operate & No & $58(33.7 \%)$ \\
\hline Rent payment condition of the MSE work premises & Yes & $113(65.7 \%)$ \\
\cline { 2 - 3 } & No & $59(34.3 \%)$ \\
\hline Availability of raw materials for the product/service & Yes & $103(59.9 \%)$ \\
\cline { 2 - 3 } & No & $69(40.1 \%)$ \\
\hline Availability of market for the product/services of MSE & Yes & $108(62.8 \%)$ \\
\cline { 2 - 3 } & No & $64(37.2 \%)$ \\
\hline The existence of market linkage of MSE with other & Yes & $60(34.9 \%)$ \\
\cline { 2 - 3 } organization & No & $112(65.1 \%)$ \\
\hline Support provided for MSE from MSE support & Yes & $119(69.2 \%)$ \\
\hline institutions & No & $53(30.8 \%)$ \\
\hline Corruption problem from the MSE support institutions & Yes & $25(14.5 \%)$ \\
\cline { 2 - 3 } & No & $147(85.5 \%)$ \\
\hline
\end{tabular}

Source: Own survey, 2015

Table 4: External environment related determinants of entrepreneurs drop out. 
Citation: Waktola AD, Hirpha MA (2016) Analysis of the Main Cause for the Entrepreneurs Drop Out in Micro and Small Enterprises: Evidences from Nekemte Town, Eastern Wollega Zone, Oromia Regional State, Ethiopia. Int J Econ Manag Sci 5: 376. doi: 10.4172/2162-6359.1000376

Page 7 of 16

that $103(59.9 \%)$ of the respondent reported that they are easily access raw material for their business whereas the remaining $69(40.1 \%)$ of the respondents reported that they do not easily get raw material on demand. The result of the study is in line with the result of the study conducted by Assefa, Zerfu and Tekle that shows the major challenges that hampers the growth and development of MSEs in Ethiopia is access to sufficient and sustainable market for the product as well as the raw materials they used in the production. Lack of market adversely affects the business and makes entrepreneurs become dissatisfied in their operation.

The MSE support package helps to create an enabling business environment by offering of direct policy support by government devising targeted and specific support programs such as access to finance, access to appropriate training and technology, marketing linkage, provision of physical infrastructures and access to working and selling spaces and other handholding supports that deemed appropriate. The result of the study shows that 119 (69.2\%) of the respondents reported that they have acquired the necessary support package from MSE support institutions whereas the remaining $53(30.8 \%)$ of the respondents reported that they did not get any support from MSE support institutions. The result of the study is in line with the existing literature that states the MSE support is found at the infancy stage in the provision of industry extension service with the objectives to make MSEs competent enough in the market to enable them to generate sufficient and sustainable job opportunities thereby improving their income. However, the infancy of the industry extension service may have an impact on the growth of MSE business leading to members' dissatisfaction to their business. Similarly, among the support package, It is only $60(34.9 \%)$ of the respondents that acquired market linkage whereas $112(65.1 \%)$ the respondents do not get any market linkage. Due to failures to properly use the market linkage opportunities, MSEs have failed to serve their debts timely; their products could not be sold or are sold at loss. The result of the study is in line with the study conducted by Stevenson and St-Onge reveals that the first challenges for entrepreneurial success in Ethiopia relates to linkages. According to the authors, in Ethiopia the large and small firms compete rather than cooperate. Business cooperation through networking is not common in Ethiopia. The authors also mention that the institutional framework that enables outsourcing from large to small firms is also weak and pushes to drop out of members from their business. Finally, from the external business environmental dimension point of views, the researcher tries to see the problem of corruption is generally a barrier to the socioeconomic development and the development of entrepreneurial activity in particular. The study result reveals that it only $25(14.5 \%)$ of the respondents that are reported there is a corruption problem whereas the majority of the respondents $147(85.5 \%)$ reported that the MSE support institutions are free of corruption for the support they provide for the entrepreneurs. The level of corruption in the study area is insignificant indicating that the policies and strategies that reduce corruption appear to be more efficient at the town administration level.

Rate of entrepreneur dropout and contributing factor: The major determinant factors that affect success or failure of MSEs are categorized in to three dimensions point of views that can be seen from the individual entrepreneurial dimension, business or organizational dimension, and external business environmental dimensional factors.

Rate of entrepreneur dropout from the MSE business: Despite MSE are acknowledged in income generation and employment creation, the result of the study reveals that 101 (58.7\%) of the respondents reported that they face members drop out from their business whereas the remaining $71(41.3 \%)$ of them does not encountered the drop out of members from their business. The mean drop rate of the entrepreneurs is describes as follows (Table 5).

The mean of members during establishment was 4.77 with standard deviation of 4.17 , while the mean of members during the survey was 3.27 with standard deviation of 2.96. This means the total drop rate of the entrepreneurs from their business has a mean value of 1.55 with a standard deviation of 2.11 out of which a mean of 1.02 with standard deviations of 1.71 is that of male entrepreneurs dropout rate and the remaining 0.52 with standard deviation of 1.09 was female entrepreneurs drop out in the study area. This implies that there is around one third of the total entrepreneurs organized in the MSE business were dropped out at rate that accounts for 32.5 $(1.55 / 4.77=32.5 \%) \%$ of the entrepreneurs left the business since their establishment. Similarly, when the rate of drop out of the male and female entrepreneurs was considered, the result of the study shows that there is a high turnover from male entrepreneurs $(1.02 / 1.55=65.81 \%)$ as compared to that of the female $(0.52 / 1.55=33.55 \%)$ entrepreneurs counter parts.

Factors contributing for entrepreneur's dropout: The main contributing factors for the drop out of MSE members are individual, business, and external business environmental factors from the highest to lowest level of contribution. When the most serious determinant factor that contributes for members drop out from the business was seen, the result of the study reveals that the individual dimensional factor accounts the highest rate, $77(76.2 \%)$, followed by business dimensional factor that accounts for $20(19.8 \%)$ and with the lowest contributing factor being the external business environmental factors that accounts $4(4.0 \%)$ in the study area. the result of this study corroborate the existing literature that state the growth and failure of a firm are, to a certain extent, is a matter of decisions made by individual operators that is very much pronounced for MSEs that are run by owner-managers. It is also similar to the study conducted by Baum, Locke, Smith [12] indicate that personality traits, motivation, individual competencies and personal background are important factors for the success/failure of MSE from the individual dimension point of views.

Individual dimensions determinants factors: The analysis of the determinants factors that contributes for entrepreneur drop out from individual dimensions in order of their contribution shows that lack of need for achievement, risk taking propensity of the entrepreneur, entrepreneurial personal background, lack of motivation by the

\begin{tabular}{|c|c|c|c|c|c|}
\hline Variable & Obs & Mean & Std. Dev. & Min & Max \\
\hline Number of members during establishment & 172 & 4.77 & 4.17 & 2 & 34 \\
\hline Number of members during survey time & 172 & 3.27 & 2.96 & 1 & 24 \\
\hline Total drop out of number from the MSE & 171 & 1.55 & 2.11 & 0 & 10 \\
\hline Total male drop out from the MSE & 172 & 1.02 & 1.71 & 0 & 7 \\
\hline Total female drop out from the MSE & 172 & 0.52 & 1.09 & 0 & 8 \\
\hline
\end{tabular}

Source: Own computation from survey, 2015.

Table 5: The mean dropout of entrepreneurs since their establishments. 
Citation: Waktola AD, Hirpha MA (2016) Analysis of the Main Cause for the Entrepreneurs Drop Out in Micro and Small Enterprises: Evidences from Nekemte Town, Eastern Wollega Zone, Oromia Regional State, Ethiopia. Int J Econ Manag Sci 5: 376. doi: 10.4172/2162-6359.1000376

Page 8 of 16

entrepreneur, lack of competence by the entrepreneurs, and lack of locus of control by the entrepreneurs are major factor from the highest to lowest.

The result of the study reveals that lack of need for achievement of the business objective affects the most accounting for $30(29.7 \%)$ followed by risk taking propensity of members, $22(21.8 \%)$, of the enterprises of the total determinant factors that cause members drop out. The result of the study is in line with the empirical studies conducted by Wiklund, Patzelt and Shepherd contend that personality traits are reflected in individual motives to grow and sustain in the business as a key indicator of individual attribute in the firm success. It is also the same as the existing literature that states openness to risk taking is an important trait of the entrepreneur especially in Africa where entrepreneurs face uncertainties with regard to prices, demand, reliability of infrastructure and corruption indicating entrepreneurs with risk taking trait are not afraid to take risks even under uncertain conditions and thus, they tend to invest in their businesses and strive to grow by taking risks. On the other hand, risk-averse entrepreneurs choose a conservative strategy mix which has a downward impact on profitability and employment because these entrepreneurs fail to respond to uncertain future demands. Thus, lack of such risk taking propensity trait by the entrepreneurs' leads to failure of the MSE business that in turn leads to drop out of members from the business (Table 6).

Also, from the individual dimensional factors of the entrepreneurs drop out, the study result also shows that 19 (18.8\%) followed by 14

\begin{tabular}{|c|c|c|}
\hline Characteristic & Variable & $\begin{array}{c}\text { Frequency } \\
\text { (percentage) }\end{array}$ \\
\hline \multirow{2}{*}{$\begin{array}{l}\text { Existence of drop out of member from } \\
\text { MSE business }\end{array}$} & Yes & $101(58.7 \%)$ \\
\hline & No & $71(41.3 \%)$ \\
\hline \multirow[t]{3}{*}{$\begin{array}{l}\text { The most serious case for the drop out } \\
\text { of members from MSE is }\end{array}$} & $\begin{array}{l}\text { From individual } \\
\text { dimension }\end{array}$ & $77(76.2 \%)$ \\
\hline & $\begin{array}{l}\text { From business } \\
\text { dimension }\end{array}$ & $20(19.8 \%)$ \\
\hline & $\begin{array}{l}\text { From environmental } \\
\text { dimension }\end{array}$ & $4(4.0 \%)$ \\
\hline \multirow{6}{*}{$\begin{array}{l}\text { From individual entrepreneurial } \\
\text { dimension that case drop out of } \\
\text { members from MSE business in the } \\
\text { study area }\end{array}$} & $\begin{array}{l}\text { Lack of need for } \\
\text { achievement }\end{array}$ & $30(29.7 \%)$ \\
\hline & Lack of motivation & $14(13.9 \%)$ \\
\hline & Lack of competence & $12(11.9 \%)$ \\
\hline & Personal background & $19(18.8 \%)$ \\
\hline & Risk taking propensity & $22(21.8 \%)$ \\
\hline & Lack of locus of control & $4(4.0 \%)$ \\
\hline \multirow{6}{*}{$\begin{array}{l}\text { From the business dimension the most } \\
\text { serious cause for members drop out } \\
\text { from MSE are }\end{array}$} & Slow growth of the MSE & $57(56.4 \%)$ \\
\hline & Sector of the business & $4(4.0 \%)$ \\
\hline & Size of the business & $7(6.9 \%)$ \\
\hline & Age of the business & $2(2.0 \%)$ \\
\hline & Location of the business & $8(7.9 \%)$ \\
\hline & $\begin{array}{l}\text { Supply and demand } \\
\text { problem }\end{array}$ & $23(22.8 \%)$ \\
\hline \multirow{7}{*}{$\begin{array}{l}\text { From the external business } \\
\text { environment dimension that case }\end{array}$} & Tax system & $13(12.9 \%)$ \\
\hline & $\begin{array}{l}\text { Legal and regulation } \\
\text { issue }\end{array}$ & $8(7.9 \%)$ \\
\hline & Work premises & $42(41.6 \%)$ \\
\hline & Societal attitude & $10(9.9 \%)$ \\
\hline & Support package & $8(7.9 \%)$ \\
\hline & Access to credit & $14(13.9 \%)$ \\
\hline & Bureaucratic system & $6(5.9 \%)$ \\
\hline
\end{tabular}

Source: Own survey, 2015

Table 6: Major categories of determinants factors for entrepreneurs drop out.
(13.9\%) of the respondents reported that members of the MSE drop out from the enterprise due to their personal background reason and lack of motivation respectively. The main motivations for why entrepreneurs start businesses can be categorized as pull and push motivations strategies [13]. Push factors are elements of necessity such as insufficient family income, dissatisfaction with a salaried job, difficulty in finding work and a need for a flexible work schedule because of family responsibilities. Pull factors relate to independence, self-fulfillment entrepreneurial drive, desire for wealth and social status. Entrepreneurs that start business due to push motivational factor of their personal background are more likely quit their business in the study area.

Similarly, the study also shows that $12(11.9 \%)$ of the respondents reported that members of the MSE drop out from the enterprise due to lack individual competences in the business respectively. An individual competency is defined as the knowledge, skills and abilities required to perform a given task. The individual competencies are categorized as general competence and specific competence. General competence refers largely to management competence and includes the individual's oral presentation skills, decision making ability, conceptualization ability and use of power; while specific competence involves technical and industry skills [14]. Empirical evidence shows that technical competences are more important determinants. Entrepreneurs that lack technical competence are more likely quit from their business in the study area.

Finally, from the individual entrepreneurial dimension, lack of locus of control by the entrepreneurs is the least factor that contributes for entrepreneur drop out. The result of the study reveals that 4 (4.0\%) of the respondents reported that as quitted entrepreneurs lack locus of control cause members drop out in the study area. Lack locus of control is the extent to which an individual believes that his/her actions can influence external factors. It is the self-confidence of the person to think that his/her actions can significantly impact on external factors. If the individual has such confidence, then she/he is said to have an internal locus of control. If an individual has an internal locus of control, she/ he not only dares to open a venture but also, strives to grow since the person thinks that she/he can change the outside world. Members of the MSE that lack locus of control are likely to quit their business than members with trait of locus of control.

Business/Organizational dimensions determinants factors: When the determinant factors are considered from the business/ organization dimension point of view, the study result shows that the major factors that contributes for the drop out of members from their business from highest to lowest level are slow growth of the MSE business, supply and demand related factors, location of the MSE business, size of the MSE business, sector of the MSE business and age of the MSE.

From the business dimension, the most serious factor that contributes for entrepreneur drop out from MSE business is slow growth of the business that accounts for more than half, 57 (5.4\%) followed by supply and demand related factor that accounts for 23 (22.8\%) of the entrepreneurs drop out from their MSE business. Also, $8(7.9 \%)$ of the respondents reported that entrepreneurs left MSE due to the problem related to location of the MSE business that they are ruining. The result of the study is in line with previous studies that show location of the business could have a direct influence on profitability and success of MSEs by affecting supply and demand conditions that have a direct implication on costs and benefits accruing to the business. Success was represented by employment growth in the business. 
Businesses located in commercial districts and on roadsides were positive and statistically significant in influencing enterprise growth rates compared to enterprises located at home. MSEs operating roadside locations and market locations were found to show a significant survival advantage compared to home-based enterprises. Location of the enterprise affects demand conditions and degree of competition. Enterprises located at commercial districts may experience better demand but they could also face stiff competition. A positive relationship between location and success can be expected if enterprises produce complementary products and are located near final demand. However, if imitative products are located together, it will lead to a higher competition and hence very small market share leading to poor performance and members' dropout by business failure.

When the size of the MSE business is considered, the result of the study shows that $7(6.9 \%)$ of the respondents reported that entrepreneurs quit from their business due to the size of the business. Size of the MSE business is measured in terms of number of member's employment representing the number of regular workers that include all working owners, paid workers, or unpaid workers in the business on a regular basis. Also it is clear that the number of members to be included in one MSE varies across sectors. Manufacturing and construction sector requires more people than trade and the service sector in which individual motives and commitment tends to declines as number of members increase in a single enterprise leading to drop out of entrepreneurs from the business.

The result of the study shows that $4(4.0 \%)$ of the respondents reported that entrepreneurs quite due to the sector of the business on which they are operating. The study result is in line with empirical studies reveal that MSE success or failure varies across sectors. The study conducted by Liedholm [15] that found manufacturing and service sector performed significantly better (higher growth rate) compared to trading sector due to the fact that enterprises in different sectors face different demands and varying cost structures. Also, there is significant difference among sectors of the MSEs on the support provided from government institutions on government projects such as cobble stone road construction, sub-contracting from housing projects and the like. As a result the lacerative support from government priority area and the highly growing sector may push members of the other sector MSE to drop their business sector and join the lucrative one.

Finally, from the business dimension point of view, age of the business is the least factor, $2(2.0 \%)$, that contributes for the drop out of entrepreneurs. Age is measured in years from the birth of the firm to the time of the survey. The result of the study is in line with existing empirical studies done by Liedholm that reveal firm growth is inversely related to initial size and age that smaller and younger firms grow faster. MSEs operating in manufacturing and service grow faster than those in trade.

External environmental dimensions determinant factors: From the external business environmental dimension point of view, the major factors that contribute for the drop out of entrepreneurs are lack of work premises, access to credit, tax system, societal attitude towards MSE legal and regulatory issues and support package. Among these, lack of work premise accounts for 42 (41.6\%) of the contributing factors for entrepreneurial drop out. The result of the study is in line with the study conducted by Ageba and Amha that indicate lack of premise and land as a major bottleneck for MSE and lack of business premises has adversely affected the growth and survival of their businesses.

The study result shows that lack of access to credit is the second most causes for entrepreneurs drop out that accounts for 14 (13.9) from external business environmental factors. The result of the study is also similar to previous study conducted by Ageba and Amha that shows lack of access to credit is another major challenge to MSE expansion in Ethiopia of which about $30 \%$ of the MSE operators replied that high collateral requirements to access credit have hampered their businesses and could force entrepreneurs either to borrow from informal financial markets at higher interest rates or quiet the business.

Also, the result of the study shows that the tax system accounts for $13(12.9 \%)$ from the external business environmental factor that contributes for entrepreneurs drop out from their business. It is clear that MSEs that are formal and properly licensed are subject to paying taxes as per the tax proclamation of the country. They are not legally obliged to keep their accounting records. As a result, the tax authorities are forced to levy arbitrarily and subjectively on MSE since do not keep complete book of records they are prone to subjective taxation. The result of the study is in line with the study conducted by Ageba and Amha which found that about $37 \%$ of the interviewed MSE operators mentioned high taxes as a major bottleneck for business expansion. This can contributes for the dissolving of the business.

When the societal attitude about the product and services of the MSE is considered, the result of the study reveals that it accounts for about $10(9.9 \%)$ of the external business environmental factor that contributes for the drop out of entrepreneurs in the study area. The attitudinal problems of the private sector towards MSEs are reflected more importantly in the way that MSEs are crowding out the private investors. This is more visible in the construction sector works in the state sponsored housing development project and infrastructure development projects that have targeted creating opportunities for MSEs. This has created the sense that MSEs are favored by the government leaving the private investors as bystanders. The various governmental support packages that prioritize MSEs have left the private investors to be more antagonistic towards MSEs. This leads to the perception that MSEs are not produce quality products that can compete with similar products.

Finally, the legal and regulatory requirements of the MSE support institution and their support package accounts 8 (7.9\%) each from the overall external business environmental factors that contributes for the drop out of entrepreneurs in the study area. A legal and regulatory system that calls for complex registration and licensing requirements and demands tedious and costly reporting practices impose heavy costs on SMEs. Such regulatory issues were specifically noted for their impact on MSE business and notable among them are restrictive labor regulations, inefficient government bureaucracy, corruption, and poor policy coordination and erratic administration of laws. The existence of such issues in turn affects the level of support to be provided for the MSE that in turn affects the individual motivation of the entrepreneurs in the study area.

Relational data (cross tabulation) of determinant factors: The individual, the business/organizational dimensions and external business environmental characterization provides the researcher better information than single characteristics of the respondents. This type of relational data would also help in comparing of different factors that contributes for the drop out of entrepreneurs from the MSE business in the study area. Such variables includes sex of the entrepreneurs, age of the entrepreneurs, educational status of the entrepreneurs, managerial skills of the entrepreneurs, technical skills of the entrepreneurs, risk taking propensity of the entrepreneurs, and strong networking capacity 
Citation: Waktola AD, Hirpha MA (2016) Analysis of the Main Cause for the Entrepreneurs Drop Out in Micro and Small Enterprises: Evidences from Nekemte Town, Eastern Wollega Zone, Oromia Regional State, Ethiopia. Int J Econ Manag Sci 5: 376. doi: 10.4172/2162-6359.1000376

Page 10 of 16

of the entrepreneurs are considered from individual dimensional factors. From the organizational dimensions sector of the business, legal form, possessing of business license, and business plan, maintain of accounting records, and profitability of the MSE business and work premises including its sufficiency, suitability and rent conditions; source of finance, availability of raw materials, existence of market for the product/services of the MSE, market linkage, support package, and corruption along with drop out of entrepreneur from the external business environments are discussed under this section.

Individual dimensions related characterization of relational data: From the individual dimensional factors, when sex of the entrepreneurs is cross tabulated with the drop out of entrepreneurs, the result of the study shows that $63.3 \%$ of drop out observed in the male entrepreneurs as compared to $47.1 \%$ of drop out in the female entrepreneurs in the study area. The result of the study is in line with the study conducted by Mead and Liedholm that argues that gender of the MSE may influence business success or failure in many that in turn have an influence on the drop out of the entrepreneurs (Table 7).

Also, when the age categories of the entrepreneurs is cross tabulated the drop out of entrepreneurs, the result of the study shows that $100 \%$ of entrepreneurs found in the age category of 46 to 60 years, $61.6 \%$ of the entrepreneurs in the age category of 30 to 45 years and $52.7 \%$ of the entrepreneurs found in the age category of 15 to 29 years shows entrepreneurs drop out. This implies as the age of the entrepreneurs increase, the rate of drop out becomes increase. The result of the study is in line with the study conducted by Welter that states the age of the entrepreneur is negatively related to success. Age of the entrepreneur is among the most determinants of entrepreneurial success and failure. It has been argued that younger entrepreneurs possess a higher growth ambition compared to older entrepreneurs and that growth ambition drives success and less frequently drops out from the business. Younger entrepreneurs are energetic, determined and willing to test their

\begin{tabular}{|c|c|c|c|}
\hline \multirow[t]{3}{*}{ Characteristic } & \multirow[t]{3}{*}{ Variable } & \multicolumn{2}{|c|}{$\begin{array}{c}\text { Members dropped from } \\
\text { MSE }\end{array}$} \\
\hline & & Yes & No \\
\hline & & $\begin{array}{c}\mathrm{N} \\
\text { (percentage) }\end{array}$ & $\begin{array}{c}\mathrm{N} \\
\text { (percentage) }\end{array}$ \\
\hline \multirow[t]{2}{*}{ Sex of the entrepreneurs } & Male & $69(66.3 \%)$ & $35(33.7 \%)$ \\
\hline & Female & $32(47.1 \%)$ & $36(52.9 \%)$ \\
\hline \multirow[t]{3}{*}{ Age category of respondents } & 15 to 29 years & $48(52.7 \%)$ & $43(47.3 \%)$ \\
\hline & 30 to 45 years & $45(61.6 \%)$ & $28(38.4 \%)$ \\
\hline & 46 to 60 years & $8(100 \%)$ & $0(0.0 \%)$ \\
\hline \multirow{5}{*}{$\begin{array}{l}\text { Educational status of the } \\
\text { respondents }\end{array}$} & Below high school & $30(63.8 \%)$ & $17(36.2 \%)$ \\
\hline & $\begin{array}{l}\text { High school } \\
\text { complete }\end{array}$ & $24(55.8 \%)$ & $19(44.2 \%)$ \\
\hline & TVET graduate & $26(63.4 \%)$ & $15(36.6 \%)$ \\
\hline & College Diploma & $8(38.1 \%)$ & $13(61.9 \%)$ \\
\hline & $\begin{array}{l}\text { First degree and } \\
\text { above }\end{array}$ & $13(65.0 \%)$ & $7(35.0 \%)$ \\
\hline \multirow{2}{*}{$\begin{array}{l}\text { Networking capacity of the } \\
\text { entrepreneurs }\end{array}$} & Yes & $51(58.6 \%)$ & $36(41.4 \%)$ \\
\hline & No & $50(58.8 \%)$ & $35(41.2 \%)$ \\
\hline \multirow{2}{*}{$\begin{array}{l}\text { Managerial skill of the } \\
\text { entrepreneurs }\end{array}$} & Yes & $81(54.4 \%)$ & $68(45.6 \%)$ \\
\hline & No & $20(87.0 \%)$ & $3(13.0 \%)$ \\
\hline \multirow{2}{*}{$\begin{array}{l}\text { Technical skills of the } \\
\text { entrepreneurs }\end{array}$} & Yes & $73(54.1 \%)$ & $62(45.9 \%)$ \\
\hline & No & $28(75.7 \%)$ & $9(24.3 \%)$ \\
\hline \multirow{2}{*}{$\begin{array}{l}\text { Risk taking capacity of the } \\
\text { entrepreneurs }\end{array}$} & Yes & $93(60.0 \%)$ & $62(40.0 \%)$ \\
\hline & No & $8(41.7 \%)$ & $9(52.9 \%)$ \\
\hline
\end{tabular}

Source: Own survey, 2015

Table 7: Cross tabulation of individual related factors of members drop out. abilities and hence possess greater growth goals compared to older entrepreneurs that lead them to drop out from their business (Table 8).

When the educational status of the entrepreneurs was cross tabulated with the drop out of the entrepreneurs, the result of the study shows that the highest entrepreneurs drop out from their business is observed in those with first degree and above that accounts for $65 \%$ followed by entrepreneurs with educational achievements of below high school that accounts for $63.8 \%$. Also the drop out of TVET graduate are accounts for $63.4 \%$ with the lowest rate being entrepreneurs with diploma level of educational achievements that accounts for $38 \%$ in the study area. This is in line with the study conducted by Bates [16] that found that educational level of the proprietor is positively and significantly related to the firm's longevity as well as the retention of members, which is an indicator of success. The study that shows the highest drop rate of entrepreneurs with degree and above educational achievements confirms the study conducted by Goedhuys and Sleuwagen [17] that argues higher education not only raises enterprise performance, but also increases outside options such as wage employment.

Similarly, when the networking capacity of the entrepreneurs is cross tabulated with the drop out of entrepreneurs, the result of the study reveals that the rate of drop out of the entrepreneurs is almost the same that accounts $58.8 \%$ dropout rate in entrepreneurs that lack networking capacity as compared to $58.6 \%$ of entrepreneurs with the capacity of net working in the study area. The study is in line with the study conducted by Stevenson and St-Onge that reveals business cooperation through networking is not common in Ethiopia. The authors also mention that the institutional framework that enables outsourcing from large to small firms is also weak indicating lack of networking technical support leads to entrepreneurs drop out from their business in the study area.

When the manager skill of the entrepreneurs is cross tabulated with the level of entrepreneurs drop out, the result of the study shows that $87 \%$ of drop out is observed in entrepreneurs that lack managerial skill

\begin{tabular}{|c|c|c|c|}
\hline \multirow[t]{3}{*}{ Characteristic } & \multirow[t]{3}{*}{ Variable } & \multicolumn{2}{|c|}{$\begin{array}{l}\text { Is members dropped from } \\
\text { MSE? }\end{array}$} \\
\hline & & Yes & No \\
\hline & & $\begin{array}{c}\mathbf{N} \\
\text { (percentage) }\end{array}$ & $\begin{array}{c}\mathrm{N} \\
\text { (percentage) }\end{array}$ \\
\hline \multirow{5}{*}{$\begin{array}{l}\text { Sector of the MSE business } \\
\text { in which the respondents } \\
\text { operating }\end{array}$} & Industry & $21(72.4 \%)$ & $8(27.6 \%)$ \\
\hline & Service & $41(54.6 \%)$ & $34(45.4 \%)$ \\
\hline & Construction & $11(91.6 \%)$ & $1(8.4 \%)$ \\
\hline & Agriculture & $6(54.5 \%)$ & $5(45.5 \%)$ \\
\hline & Trade & $22(48.8 \%)$ & $23(51.2 \%)$ \\
\hline \multirow{2}{*}{$\begin{array}{l}\text { Legal form of respondents MSE } \\
\text { business }\end{array}$} & Partnership & $57(44.8 \%)$ & $70(55.2 \%)$ \\
\hline & Cooperative & $44(97.7 \%)$ & $1(2.3 \%)$ \\
\hline \multirow{2}{*}{$\begin{array}{l}\text { Possessing of business license } \\
\text { by the MSE }\end{array}$} & Yes & $91(61.9 \%)$ & $56(38.1 \%)$ \\
\hline & No & $10(40.0 \%)$ & $15(60.0 \%)$ \\
\hline \multirow{2}{*}{$\begin{array}{l}\text { Possessing of business plan by } \\
\text { the MSE }\end{array}$} & Yes & $31(72.0 \%)$ & $12(28.0 \%)$ \\
\hline & No & $70(54.3 \%)$ & $59(45.7 \%)$ \\
\hline \multirow{2}{*}{$\begin{array}{l}\text { Accounting and record keeping } \\
\text { of the MSE }\end{array}$} & Yes & $47(63.5 \%)$ & $27(36.5 \%)$ \\
\hline & No & $54(55.1 \%)$ & $44(44.9 \%)$ \\
\hline \multirow{2}{*}{$\begin{array}{l}\text { Profitability of the MSE business } \\
\text { of the respondent }\end{array}$} & Yes & $81(56.2 \%)$ & $63(43.8 \%)$ \\
\hline & No & $20(71.4 \%)$ & $8(28.6 \%)$ \\
\hline \multirow{4}{*}{$\begin{array}{l}\text { Source of finance for the MSE } \\
\text { business to start business } \\
\text { operation }\end{array}$} & MFI institution & $23(59.0 \%)$ & $16(41.0 \%)$ \\
\hline & Personal saving & $57(62.6 \%)$ & $34(37.4 \%)$ \\
\hline & Loan from NGOs & $15(79.0 \%)$ & $4(21.0 \%)$ \\
\hline & Relative/friend & $6(26.0 \%)$ & $17(74.0 \%)$ \\
\hline
\end{tabular}

Source: Own survey, 2015

Table 8: Cross tabulation of business related factors of members drop out 
as compared to $54.4 \%$ entrepreneurs drop out from enterprises having the required managerial skills. The result of the study is in line with the study conducted by Musara and Gwaindepi [18] states that the key challenges to the long term survival and viability of small businesses and enterprises are lack of basic entrepreneurial and managerial skills that are required by entrepreneurs. The growth/failure of a firm is, to a certain extent, a matter of decisions made by individual operators which is very much pronounced for microenterprises that are run by owner-managers.

Also, when the technical skill of the entrepreneurs is cross tabulated with the drop out of entrepreneurs, the result of the study shows that $75.7 \%$ of the entrepreneurs drop out is observed in entrepreneurs that lack technical skill as compared with $54.1 \%$ drop out of entrepreneurs with the capacity of technical skill required for the business in the study area. The result of the study is in line with the empirical evidence shown by Baum, Locke, and Smith, states that technical competences and skill of the entrepreneurs are the most important determinants of business success or failure.

Finally, from the individual dimensional factor, when the risk taking capacity of the entrepreneurs is cross tabulated with the drop out of entrepreneurs, the result of the study reveals that the highest dropout of entrepreneurs is observed in entrepreneurs that have risk taking capacity for the development of the business that accounts $60 \%$ as compared to $41.7 \%$ of entrepreneurs that lack risk taking capacity for their business. The study result was in line with the study conducted by Casser (2007) that has shown a positive and significant relationship between risk taking of an entrepreneur and business success. Entrepreneurs with risk taking trait are not afraid to take risks even under uncertain conditions. Thus, they tend to left unprofitable business and invest in other businesses and strive to grow by taking risks.

Business/Organizational related characterization of relational data: When the cross tabulation of business sector drop out of entrepreneurs from MSEs business is considered, the result of the study reveals that the construction sector accounts the highest rate, $91.6 \%$ followed by the industry sector $(72.4 \%)$ with the lowest rate being the trade sector that accounts $48.8 \%$ drop rate from the enterprise. The dropout rate of entrepreneurs from service sector and agricultural sector accounts around $54.5 \%$ each. There is significant difference in the rate of entrepreneurs among sectors of the MSEs. MSEs operating on manufacturing and construction sector are mostly organized in the cooperative structure that requires more people during establishment than trade and the service sector. It is obvious that the smaller the number of member, the higher the responsibility in the business and the lower the dropout rate.

Also, when the entrepreneurs drop out is cross tabulated with the form of the business, on which the MSE are organized, the study result reveals that the dropout rate of entrepreneurs is highest in the cooperative form of organization $(97.7 \%)$ as compared to the partnership type of organization which accounts for around $44.8 \%$ rate of drop out of entrepreneurs. The cooperative form of organizational structure requires large number of entrepreneurs that the partnership type. The incentive to work hard as the number of member increase becomes decrease. As more and more entrepreneurs involve in a given business, the trust among them deteriorates and entrepreneurs drop from their business. The study also shows that the entrepreneurs' dropout rate is highest in a legally licensed MSE than that of informally operating their business without renewing their work license.
Moreover, when the variables such as owing of business plan, record keeping, and the profitability of the MSE business is cross tabulated with members drop out, the result of the study shows that the $72 \%$ of the entrepreneurs drop out is reported from respondents that have business plan. The rate of drop out of entrepreneurs from MSE operating without business plan is around $54.3 \%$. This indicates that owing a business plan is not a grantee for the retention of members in to the business. The study result also shows that the rate of drop out is highest in MSEs that have keeping accounting records (63.5\%) as compared to those who does not keep their business records that accounts for $55.1 \%$ in the study area. Finally, the highest dropout rate of entrepreneurs is observed in business that is not profitable (71.4\%) as compared to the lacerative type of business that is profitable (56.2\%) in the study area. In any business, profit is the main source of income for enterprises. An entrepreneur that has dubbed hope in future profit generation tends to leave the business as compared to the one operating in lacerative types of business.

Finally, when the source of finance for the MSE business is cross tabulated with the entrepreneurs drop out, the result of the study shows that MSE that have acquired finance loan from NGO shows the highest dropout rate that accounts around 79\% followed by enterprises that start MSE business by personal saving which is $62.5 \%$. Similarly, MSEs that are browed from MFI show an entrepreneurs dropout rate of $59 \%$. The lowest dropout rate or the highest retention of entrepreneurs in the MSE business is observed in MSE that are borrowed from relative or friends. The finding of the study indicates that entrepreneurs are reluctant to pay their debit in case the source does not have any social effects on them. This may be the reason for entrepreneurs frequent leaving their business not to timely repays their debit from any financial sources. The social value they have for their friends and relatives force them not to leave the business for a longer period of time.

External environmental related characterization of relational data: The cross tabulation of environmental business environmental factors with entrepreneurs drop out from their business tells as in which of the factors that significant drop out of members observed. In this sub section the cross tabulation of source of finance, access to raw materials, the market condition for MSE product/services, availability of work premises, its sufficiency and suitability as well as the rent condition, the market linkage, the MSE support and corruption problem was cross tabulated with entrepreneurs drop out.

When the market demand and supply of the MSE is considered, the result of the study shows that $65.2 \%$ of the entrepreneurs that left their business were those who do not have access to raw material for their operational activities. Similarly, 68.7percent of the respondents reported that entrepreneurs left their business due to lack of market for their business product/services in the study area. The result of the study is in line with the existing study that confirms as availability of sufficient and suitable market for the product/services of an enterprise is one of the major challenges that hampers the growth and development of MSEs in Ethiopia. Lack of the growth of the business reduces the incentive to work hard and leads to drop out of entrepreneurs from their business (Table 9).

Also, when factors associated with the work premises of the enterprise was cross tabulated with entrepreneurs drop out from their business; the result of the study shows that $63.2 \%$ of the respondents reported that entrepreneurs left the business due to lack of work premises, $67.1 \%$ of them left due to the sufficiency of the work premise in which they are operating, $65.5 \%$ of the respondents reported that 
Citation: Waktola AD, Hirpha MA (2016) Analysis of the Main Cause for the Entrepreneurs Drop Out in Micro and Small Enterprises: Evidences from Nekemte Town, Eastern Wollega Zone, Oromia Regional State, Ethiopia. Int J Econ Manag Sci 5: 376. doi: 10.4172/2162-6359.1000376

Page 12 of 16

\begin{tabular}{|l|c|c|c|}
\hline \multirow{2}{*}{ Characteristic } & Variable & \multicolumn{2}{|c|}{ Is members dropped from } \\
MSE?
\end{tabular}

Source: Own survey, 2015

Table 9: Cross tabulation of external environmental factors for entrepreneurs drop out.

entrepreneurs left the MSE due to lack of suitable work premises for their product/services and $64.4 \%$ of them reported that entrepreneurs dropped from the MSE due to the cost of rent of work premises in the study area. The result of the study is in line with the existing literature that states access to working and sales premises are the most challenges to MSEs operating in the country and the issue of rent is unaffordable in certain town by startup MSE who are aspiring to start business.

Finally, when determinant variables that are related to the MSE support is cross tabulated with entrepreneurs drop out from MSE, the result of the study shows that around $50 \%$ of the respondents reported that entrepreneurs left their business due to lack of market linkage and due to lack of support from MSE support institution each, and 53.1 of the respondents reported that the entrepreneurs left the business due the corruption problem that prevails among the MSE support institutions. It is clear that institutional environment has strong contribution for the success or frailer of the business that in turn has the same effect on the drop out and retention. It emphasize on the role that legal, regulatory and institutional frameworks play on microenterprise operators. The study is in line with the study conducted by Stevenson and St-Onge reveals that the first challenges for entrepreneurial success in Ethiopia relates to market linkages that stated the large and small firms compete rather than cooperate. Business cooperation through networking is not common in Ethiopia. The authors also mention that the institutional framework that enables outsourcing from large to small firms is also weak. This leads to drop out of entrepreneurs from the business.

\section{Econometric analysis}

The relationship between firm members' survival and predictor variables that affect a binary outcome variable of study, such as survival or drop out of entrepreneurs from their business can successfully be explained by using the binary logistic regression model $[19,20]$. The determinant factors that contribute for the entrepreneurs drop out from the business alone are not sufficient enough to grasp full understanding about the causative agents. It becomes complete to make any concrete recommendation when the severity of the causative agents for the drop out entrepreneurs is determined by multivariate regression analysis following the binary logistic regression.

Binary logistic regression analysis: Before conducting binary logistic regression, all the necessary econometric tests of the data were conducted to avoid problem of autocorrelation, multicollinearity and hetroscidaticity and others in the analysis.

Binary logistic regression is used explain the non-linear relationship between a dichotomous dependent variable of (yes, no) and several predictor variables that affect drop out of entrepreneurs from their business in one way or another. In binary logistic regression analysis the econometric measure of effect is the odds ratio is an estimate that is readily available in regression. The outcome or dependent variable, drop out, is dichotomous and has only two possible values ( 1 if the entrepreneurs drop out, 0 otherwise) in the study. The value of 1 indicates that there is a drop out of entrepreneurs from the MSE business since their establishment. The value 0 indicates that there is no entrepreneurs drop out from the MSE business since their establishment.

In binary logistic regression becomes, influential predicator variables are characterized by odds ratios that are significantly different from 1; 95\% confident intervals of odds ratios that do not contain 1; and $\mathrm{P}$-values that are smaller than 0.05 , at the $5 \%$ level of significance. The $\mathrm{P}$-value from the log likelihood ratio is equal to $0.0000<0.05$. This shows that the 18 predictor variables constituting the fitted logistic regression model were jointly significant in explain the drop out of entrepreneurs of 172 MSEs in the study. The proportion of the explained variations by fitted value of the model was equal to $58.61 \%$ which is above $40 \%$ that is required in primary data, and shows that the fitted model is reliable.

Accordingly, 10 of the 18 variables used for the binary logistic regression analysis are highly influential over the drop out of entrepreneurs from their business. The 10 significantly contributing factors for the drop out the entrepreneurs from their business include: sex of the entrepreneurs; age of the entrepreneurs; educational status; sector of the business; source of finance for the business; form of the business; possessing business plan for the business; existence of sufficient market for the product/services of the business; networking capacity of the entrepreneurs; and corruption from MSE support institutions in the study area.

The condition of being fulfilling the formality of renewing work license every year and being not conducting the requirement for business (informality) has an influence on the drop out of entrepreneurs at $10 \%$ level of significance. According to the study conducted by Assefa, Zerfu, and Tekle, most of the reasons that are attributed to the informality of the MSE are high transaction costs during licensing, contraband, illegal under invoicing of imports. Also the author stated that the main cause of informality is tax avoidance or fear of exorbitant taxation. This leads members of the enterprise to operate as informal and finally lead to leave the business in case the problem becomes severe from administrative structure.

Similarly, the status of market linkage that the MSE business has with other institution and other MSEs has an influence on the drop out of entrepreneurs at $10 \%$ level of significance. The study conducted by Stevenson and St-Onge reveals that the first challenges for entrepreneurial success in Ethiopia relates to linkages. According to the authors, in Ethiopia the large and small firms compete rather than cooperate. Also, the study conducted by Assefa, Zerfu and Tekle 
Citation: Waktola AD, Hirpha MA (2016) Analysis of the Main Cause for the Entrepreneurs Drop Out in Micro and Small Enterprises: Evidences from Nekemte Town, Eastern Wollega Zone, Oromia Regional State, Ethiopia. Int J Econ Manag Sci 5: 376. doi: 10.4172/2162-6359.1000376

confirms as the market linkage is influential for entrepreneurs drop out by stating that most of the government induced linkages which target holidays and festivities create only temporary jobs. Those MSEs who are beneficiaries from government support all the time and lack personal initiatives to search for market by themselves. Due to failures to properly use the market linkage opportunities, MSEs have failed to serve their debts timely; their products could not be sold or are sold at loss. This in turn contributes for the drop out of the entrepreneurs from the business (Table 10).

Also, the risk taking capacity of the entrepreneur for the growth and development of their entrepreneurs affect the drop out of entrepreneurs at $10 \%$ level of significance. The result of the study confirms the existing empirical studies conducted by Casser [21], Bigsten and Söderbom have shown a positive and significant relationship between risk taking of an entrepreneur and business success indicating that entrepreneurs with such a trait are not afraid to take risks even under uncertain conditions. Thus, they tend to invest in their businesses and strive to grow by taking risks. On the other hand, risk-averse entrepreneurs choose a conservative strategy mix which has a downward impact on profitability and employment because these entrepreneurs fail to respond to uncertain future demands. As a result they quit from their business and change to other that is less risky [22-25].

The most influential independent variable over the drop out of entrepreneurs from their business firm is the variable corruption. It has an estimated odds ratio of 20.65; a 95\% confidence interval of (1.77, 240.54); and a P-value of 0.016 . The second most influential independent variable over the drop out of entrepreneurs from their business firm is the variable form of the MSE business. It has an estimated odds ratio of 17.15 ; a $95 \%$ confidence interval of $(4.31,68.17)$; and a P-value of 0.000 . Risk taking propensity of the entrepreneur is the third influential variable with an odds ratio of 8.07 and a P-value of 0.082 . The interpretation given for each of the significant variables in terms of odds ratios and marginal effects are described as follows in decreasing order of their strength [26].
(1) The odds ratio of the variable corruption is 20.65. This indicates that the odds of entrepreneurs drop out from their business firm whose enterprises are frequently encountered by a corruption problem during license renewal and other support from support provision from MSE support provider sectors are 20.65 times higher in comparison with the odds of drop out of entrepreneurs from a business who does not encountered a corruption problem from MSE support providing sectors. The marginal effect of the regression analysis shows that the probability of entrepreneurship drops out from their business increases by about $21.39 \%$ in the study area [27-29].

(2) The odds ratio of the variable form of business is 17.15 . This indicates that the odds (risk) of entrepreneurs drop out from their business firm that are organized as partnership or cooperative with entrepreneurs dropped are 17.15 times higher in comparison with a business that are organized as a partnerships or cooperative that are operating with all of its members. The marginal effect of the regression analysis also shows that as the intensity of form of the business decreases by one unit, the probability of entrepreneurship drops out from their business increases by about $38.15 \%$ in the study area keeping other things constant.

(3) The odds ratio of the variable sex of the entrepreneur is 4.29 . This indicates that the odds of entrepreneur drop out from their business firm whose owner manager are male entrepreneurs are 4.29 times higher in comparison with the odds of entrepreneurs drop out of a business whose owner manager are female headed. The marginal effect of the regression analysis also shows that as the firm's manager are headed by male increased by one individual keeping other things constant, the probability of entrepreneurship drops out increases by about $21.60 \%$ in the study area.

(4) The odds ratio of the variable educational status is 1.54 . This indicates that the odds of entrepreneurs drop out from their business firm whose educational achievements are lower are 1.54 times higher in comparison with the odds of entrepreneurs drop out from their business whose educational achievements are at the middle stages like TVET

\begin{tabular}{|c|c|c|c|c|c|c|c|}
\hline Drop out of entrepreneurs & Odds Ratio & Std. Err. & $\mathbf{z}$ & $P>z$ & {$[95 \%$ Conf. } & Interval] & Marginal effect \\
\hline Sex of entrepreneurs & 4.297664 & 2.241344 & 2.8 & $0.005^{\star \star *}$ & 1.546353 & 11.94418 & 0.2160202 \\
\hline Age of entrepreneurs & 1.117409 & 0.038876 & 3.19 & $0.001^{* * *}$ & 1.043753 & 1.196262 & 0.0149062 \\
\hline Education status & 1.542937 & 0.3224667 & 2.08 & $0.038^{* *}$ & 1.024356 & 2.324049 & 0.0582332 \\
\hline Business sector & 0.6607076 & 0.1199972 & -2.28 & $0.022^{\star *}$ & 0.4628229 & 0.9432002 & -0.0556493 \\
\hline Business license & 4.342163 & 3.30134 & 1.93 & $0.053^{*}$ & 0.9784508 & 19.26963 & 0.2670028 \\
\hline Source of finance & 0.3180888 & 0.1116408 & -3.26 & $0.001^{* * *}$ & 0.1598818 & 0.6328455 & -0.1538014 \\
\hline Work experience & 1.631797 & 0.9916338 & 0.81 & 0.42 & 0.4959022 & 5.369532 & 0.0706235 \\
\hline Form of business & 17.14672 & 12.07504 & 4.04 & $0.000^{* * *}$ & 4.312701 & 68.17308 & 0.3815825 \\
\hline Managerial skill & 0.1400065 & 0.1811685 & -1.52 & 0.129 & 0.0110839 & 1.768494 & -0.1648612 \\
\hline Technical skill & 0.5688331 & 0.5248876 & -0.61 & 0.541 & 0.0932274 & 3.470774 & -0.0679284 \\
\hline Having business plan & 0.2002567 & 0.1470355 & -2.19 & $0.029^{* *}$ & 0.0474903 & 0.8444406 & -0.2756511 \\
\hline Market for product & 0.2555643 & 0.1708843 & -2.04 & $0.041^{* *}$ & 0.0689192 & 0.9476766 & -0.1654037 \\
\hline Business profitability & 0.5954884 & 0.5150769 & -0.6 & 0.549 & 0.1092983 & 3.244392 & -0.0617527 \\
\hline Work premises & 2.581302 & 2.042184 & 1.2 & 0.231 & 0.547539 & 12.16922 & 0.1511472 \\
\hline Market linkage & 3.620254 & 2.70147 & 1.72 & $0.085^{\star}$ & 0.8386173 & 15.62839 & 0.1535143 \\
\hline Risk taking capacity & 8.077338 & 9.691302 & 1.74 & $0.082^{*}$ & 0.7691036 & 84.83043 & 0.4215201 \\
\hline Networking capacity & 0.1147279 & 0.0750493 & -3.31 & $0.001^{* * *}$ & 0.0318314 & 0.4135067 & -0.2969112 \\
\hline Corruption & 20.65414 & 25.87066 & 2.42 & $0.016^{* *}$ & 1.773459 & 240.5431 & 0.2139255 \\
\hline
\end{tabular}

Number of obs $=172$ Log likelihood $=-98.963814$

Wald chi2(18) $=58.61$ Prob $>$ chi $2=0.0000$

${ }^{* * *},{ }^{* *}$, and ${ }^{*}$ indicates the level of significance of variables at $1 \%, 5 \%$ and $10 \%$ respectively.

Source: Own Computation from Survey Data, 2015.

Table 10: Estimates obtained from binary logistic regression analysis. 
Citation: Waktola AD, Hirpha MA (2016) Analysis of the Main Cause for the Entrepreneurs Drop Out in Micro and Small Enterprises: Evidences from Nekemte Town, Eastern Wollega Zone, Oromia Regional State, Ethiopia. Int J Econ Manag Sci 5: 376. doi: 10.4172/2162-6359.1000376

Page 14 of 16

complete and Diploma graduates. The marginal effect of the regression analysis also shows that as the education level of the entrepreneurs' decreased by one grade, the probability of entrepreneurship drops out increases by about $5.82 \%$ in the study area. This is in line with the study conducted by Bates that found that educational level of the proprietor is positively and significantly related to the firm's longevity as well as the retention of members, which is an indicator of success.

(5) The odds ratio of the variable age of the entrepreneurs is 1.11. This indicates that the odds of entrepreneurs drop out from their business firm whose ages are older and in the higher category of 46 to 60 years old are 1.11 times higher in comparison with the odds of entrepreneurs from their business whose owner has younger age category of 15 to 29 years. The marginal effect of the regression analysis also shows that as the age of entrepreneurs' increased by one year, the probability of entrepreneurship drops out increases by about $1.19 \%$ in the study area keeping other things citrus Paribas.

(6) The odds ratio of the variable business sector is 0.66 . This indicates that the odds of entrepreneurs drop out from a construction sector of business firm whose number of member are higher as compared to the rest of the business sector is 0.66 times higher than that of the trade business sector whose number of members are relatively lower. The marginal effect of the regression analysis also shows that as the number of construction firm decreased by one, the probability of entrepreneurship drops out decreases by about $5.56 \%$ in the study area by keeping other things constant.

(7) The odds ratio of the variable source of finance is 0.32 . This indicates that the odds of entrepreneurs drop out from a business firm whose source of finance is loan from NGO and MFI are 0.32 times higher in comparison with the odds of entrepreneurs drop out of a business whose source of finance is from relative/friends that have high social values. The marginal effect of the regression analysis also shows that as the source of finance is from relative/friends increased by one unit, the probability of entrepreneurship drops out decreased by about $15.38 \%$ in the study area keeping other source citrus Paribas.

(8) The odds ratio of the variable good market for product/services is 0.25 . This indicates that the odds of entrepreneurs drop out from a business firm that has experienced lack of market for their product/ services are 0.25 times higher in comparison with a business firm that has experienced good market for their product/services. The marginal effect of the regression analysis also shows that as the firms' market access for their product/services increased by one, the probability of entrepreneurship dropout decreased by about $16.54 \%$ in the study area keeping other things constant.

(9) The odds ratio of the variable business plan is 0.20 . This indicates that the odds of entrepreneurs from a business firm that are guided by a business plan are 0.20 times higher in comparison with the odds of entrepreneurs drop out from a business that is operating without business plan. The marginal effect of the regression analysis also shows that if the firm has the business plan, the probability of entrepreneurship drops out decreases by about $27.56 \%$ in the study area keeping other things citrus Paribas.

(10) The odds ratio of the variable networking capacity is 0.11 . This indicates that the odds of entrepreneurs drop out from business firm who lacks networking capacity are 0.11 times higher in comparison with the odds of entrepreneurs drop out from a business that have the required networking capacity. The marginal effect of the regression analysis also shows that as the firms networking capacity increased by one unit, the probability of entrepreneurship drops out decreases by about $29.69 \%$ in the study keeping other things constant.

Multivariate regression analysis: However, the study aims to investigate the severity of the determinant factor of MSE in maintaining members of the enterprise using a multivariate regression analysis that emphasizes on individual dimension, firm/business dimension and external environmental factors dimension. Before conducting multivariate regression, all the necessary tests are conducted and the result of the regression analysis shows as there is no problem of autocorrelation, multicollinearity and hetroscascidaticity in the model. The results of the regression analysis are described as follows (Table 11).

The model is also adequate and the result of the regression analysis shows that the independent variables explain $93.23 \%$ of the drop out of entrepreneurs from MSE business in the study area as represented by the R2. This means that other factors not studied in this research contribute to the drop out of entrepreneurs from their business only $6.77 \%$ in the town. The P-value from the multivariate regression analysis is equal to $0.0000<0.05$. This shows that the independent variables constituting the fitted multivariate regression model were jointly significant in explaining the drop out of entrepreneurs of 172 MSEs in the study. Hence, the multivariate analysis models that obtained from the regression analysis become:

Drop out $=0.59+0.033 \mathrm{ID}+0.007 \mathrm{FD}+0.002 \mathrm{EF}-0.002 \mathrm{CF}_{1}-0.005 \mathrm{CF}_{2}$

Where;

Drop out (DO) represents the number of member of the MSE that left their business from the year MSEs are established to the survey year;

Individual dimension (ID) that represents summation of the result of variables related to individual dimensions that contribute to entrepreneurs drop out from their business;

Firm dimension (FD) that represents the summation of the results business related factors that contributes for the entrepreneurs drop out from their business;

\begin{tabular}{|c|c|c|c|c|c|c|}
\hline & Coef. dropout & Std. Err. & $\mathbf{t}$ & P>t & [95\% Conf. & Interval] \\
\hline Individual dimension (ID) & 0.0330716 & 0.0036756 & 9 & 0 & 0.0258146 & 0.0403286 \\
\hline Firm dimension (FD) & 0.0070096 & 0.0046289 & 1.51 & 0.132 & -0.0021296 & 0.0161487 \\
\hline External factors (EF) & 0.0020003 & 0.0046614 & 0.43 & 0.668 & -0.007203 & 0.0112036 \\
\hline Sub-city (CF1) & -0.0018478 & 0.005924 & -0.31 & 0.755 & -0.013544 & 0.0098483 \\
\hline Sector of the business (CF2) & -0.0045711 & 0.0067668 & -0.68 & 0.5 & -0.0179311 & 0.0087889 \\
\hline Cons & 0.0597399 & 0.0322325 & 1.85 & 0.066 & -0.0038986 & 0.1233785 \\
\hline
\end{tabular}

Prog $=6$ R-sq $=0.9323 \mathrm{P}=0.0000$

Source: Own computation from survey data, 2015

Table 11: Result obtained from multivariate regression analysis. 
Citation: Waktola AD, Hirpha MA (2016) Analysis of the Main Cause for the Entrepreneurs Drop Out in Micro and Small Enterprises: Evidences from Nekemte Town, Eastern Wollega Zone, Oromia Regional State, Ethiopia. Int J Econ Manag Sci 5: 376. doi: 10.4172/2162-6359.1000376

Page 15 of 16

External factors (EF) that represent the summation of external business environmental factors that contributes for the drop out of entrepreneurs from their business;

Controls factor (CF) represent variables such as sub city of the entrepreneurs and sector of the business that are entered into regression to partial out their effects from the relationship of principal interest.

In the estimation of the severity of the multidimensional factors, the regression model applied in this study shows that the coefficient 0.59 represents estimated values of constant effect on members drop out from their business. In the same token, coefficient 0.033 , 0.007 , and 0.002 represents the estimated values for the effect of individual dimensional factors, firm dimensional factors, and external environmental dimensional factors respectively that are the main contributors for entrepreneurs drop out from their business.

The multivariate regression results for all determinants of MSE shows that individual dimensional affects positively the drop out of entrepreneurs from MSE business significantly at $1 \%$ level of significance. From the regression equation established, taking all the factors (all independent variables in regression model) constant at zero, the drop out entrepreneurs from MSE business would be increased by 0.59 . This implies that in the absence of the above dependent variable, members of the MSE drop out from their business. Furthermore, if all the other variables are kept constant, a unit increases in individual dimensional factors of the entrepreneur lead to a 0.033 drop out of entrepreneurs from their MSE business. Also, a unit increase in firm/ business dimensional factors of the entrepreneur will lead to a 0.007 drop out of entrepreneurs from MSE business. Finally, a unit increase in external business environmental factors will lead to a 0.002 drop out of entrepreneurs in the study area. This study results imply that individual dimensional factors contribute the most to the drop out of entrepreneurs from their business in the study area.

\section{Summary and Conclusion}

\section{Summary of the findings}

This section describes the main findings of the study. The study analyzed data collected from 172 entrepreneurs of which $60.5 \%$ are male and $39.5 \%$ of are female that are operating in the six sub city of the town. The study shows that more than half of the entrepreneurs are found in the age category of 15 to 29 years of old whereas $73(42.4 \%)$ of the entrepreneurs are found between 30 to 45 years old. More than half of the entrepreneurs have an educational achievements of high school complete and below high school that can read and write. The study shows that $128(74.4 \%)$ of the respondents are working on the managerial position who are making on the required decision about the business without educational status that helps them understanding the modern business environment that affects the growth and profitability of MSEs business.

The study reveals that 101 (58.7\%) of entrepreneurs face members drop out from their business whereas the remaining 71 (41.3\%) of them does not. The total drop rate has a mean value of 1.55 with a standard deviation of 2.11 out of which a mean of 1.02 with standard deviations of 1.71 is that of male entrepreneurs' dropout rate and the remaining 0.52 with standard deviation of 1.09 was female entrepreneurs drop out. The most contributing factor for members drop out from the business was the individual dimensional factor such accounts the highest rate, 77 (76.2\%), followed by business dimensional factor that accounts for 20 (19.8\%) and with the lowest being the external business environmental factors that accounts 4 (4.0\%) in the study area. From the individual dimension, lack of need for achievement of the business and risk taking propensity of members are the most serious cases followed by personal background and individual competence. From the business dimension, the most serious factor that contributes for entrepreneur drop out from MSE business is slow growth of the business followed by supply and demand related factors. In short, the econometric analysis from binary regression analysis reveals that 10 of the 18 variables used for the binary logistic regression analysis are highly influential over the drop out of entrepreneurs from their business. The 10 significantly contributing factors for the drop out of the entrepreneurs from their business include: sex of the entrepreneurs; age of the entrepreneurs; educational status; sector of the business; source of finance for the business; form of the business; possessing business plan for the business; existence of sufficient market for the product/services of the business; networking capacity of the entrepreneurs; and corruption from MSE support institutions in the study area.

In general, the multivariate regression results for all determinants of MSE shows that individual dimensional affects positively the drop out of entrepreneurs from MSE business significantly at $1 \%$ level of significance indicating that if all the other variables are kept constant, a unit increases in individual dimensional factors of the entrepreneur lead to a 0.033 drop out of entrepreneurs from their MSE business indicating that individual dimensional factors contribute the most to the drop out of entrepreneurs from their business in the study area.

\section{Conclusion}

Despite MSEs remain an important contributor to economic growth and employment creation in Ethiopia; there are many factors from the individual entrepreneurs, business dimensions as well as external business dimensions that contribute for the drop out of members from their business. These are not the sole problem of the entrepreneurs but also lack of enabling business task environment from the support institution that caused them to left from their business. The result of the study was also in line with the existing literature and studies that was conducted by other researchers in Ethiopia and outside of the country. Solving such problems need the collaborative effect of the entrepreneurs and the government and other stakeholders.

\section{References}

1. Brhane T (2014) Access to Finance for Micro and Small Enterprises in Debre Markos Town Ethiopia. Global Journal of Current Research 2: 36-46.

2. Kefale M, Chinnan P (2012) Employment growth and challenges in small and micro enterprises Woldiya, North East Amhara region, Ethiopia. Educational Research and Essays 1: 21-26.

3. Belay F (2012) Determinants of Microenterprise Success in the Urban Informal Sector of Addis Ababa: A Multidimensional Analysis. Netherlands: International Institute of Social Studies.

4. Mohammed A, Habtamu W, Dessalegn B (2014) Constraints and Growth Potentials of Micro and Small Enterprises: Case from Mekelle City. International Journal of Scientific and Research Publications 4: 1-7.

5. CSA (2003) Annual Report on Micro and Small Scale Enterprises. Addis Ababa: Central Statistical Authority.

6. Fatoki O (2012) An investigation into the financial management practises of micro-enterprises in South Africa. Journal of Social Sciences 33: 179-188.

7. Wiklund J, Patzelt $H$, Shepherd A (2007) Building an integrative model of small business growth. Small Business Economics 32: 351-374.

8. Eshetu T, Ketema M, Kassa B (2013) Economic Impact of Support Service Program on Micro and Small Enterprises: The Case of Dire Dawa Administration Ethiopia. Agris on-line Papers in Economics and Informatics 5: 21-29. 
Citation: Waktola AD, Hirpha MA (2016) Analysis of the Main Cause for the Entrepreneurs Drop Out in Micro and Small Enterprises: Evidences from Nekemte Town, Eastern Wollega Zone, Oromia Regional State, Ethiopia. Int J Econ Manag Sci 5: 376. doi: 10.4172/2162-6359.1000376

9. Zemenu A, Mohammed M (2014) Determinants of Growth of Micro and Small Enterprises in Ethiopia:A Case of MSEs in Mekelle City, Tigray. International Journal of Advance Research in Computer Science and Management Studies 2: 149-157.

10. Baum J, Locke E, Smith K (2001) A multidimensional model of venture growth. Academy of Management Journal 44: 292-303.

11. Liedholm C (2002) Small firm dynamics: Evidence from Africa and Latin America. Small Business Economics 18: 227-242.

12. Shane S, Locke E, Collins C (2003) Entrepreneurial motivation. Human Resource Management Review 13: 257-280

13. Schjoed L, Shaver K (2007) Deciding on an entrepreneurial career: A test of the pull hypothesis using the panel study of entrepreneurial dynamics data. Entrepreneurship Theory and Practice 31: 733-752.

14. Martin G, Staines H (1994) Managerial competences in small firms. Journal of Management Development 13: 23-34.

15. Mead D, Liedholm C (1998) The Dynamics of Micro and Small Enterprises in Developing Countries. World Development 26: 61-74

16. Bates T (1990) Entrepreneur human capital inputs and small business longevity. Review of Economics and Statistics 72: 551-559.

17. Goedhuys M, Sleuwaegen L (2000) Entrepreneurship and growth of entrepreneurial firms in Côte d'Ivoire'. The Journal of Development Studies 36: 123-145.

18. Musara M, Gwaindepi C (2014) Factors within the Business Regulatory Environment Affecting Entrepreneurial Activity in South Africa. Mediterranean Journal of Social Sciences 5: 109-116

19. Cramer J (2003) Logit Models from Economics and Other Fields. London: Cambridge University Press.
20. Braga J, Bressan F, Colosimo A, Bressan A (2006) Investigating the Solvency of Brazilian Credit Union, A Proportional Hazards Model. Annals of Public and Cooperative. Economics 77: 83-106.

21. Casser G (2007) A longitudinal investigation of entrepreneur career reasons growth preferences and achieved growth. Entrepreneurship and Regional Development 19: 89-107.

22. Johnson R (1990) Toward a multi-dimensional model of entrepreneurship: The case of achievement motivation and the entrepreneur. Entrepreneurship Theory and Practice 1: 39-54.

23. Kamoyo M, Muranda Z, Mavhim F (2014) Cluster Approach to Microenterprise Development: A Comparative Study of Clustered and Isolated Wooden Furniture Enterprises in Zimbabwe. Journal of Sustainable Development in Africa 16: 14-32.

24. Katua NT (2014) The Role of SMEs in Employment Creation and Economic Growth in Selected Countries. International Journal of Education and Research 2: 461-472.

25. McPherson M (1996) Growth of micro and small enterprises in Southern Africa Journal of Development Economics 48: 253-277.

26. Munyori K, Ngugi JK (2014) Factors Affecting the Growth of MSE Dairy Farmers In Kenya: Case of Gatundu South Farmer's Dairy Co-Operative Society Ltd. International Journal of Current Business and Social Sciences 1: 48-63.

27. Ndegwa K (2013) Factors Affecting Growth of Small and Medium Water Bottling Enterprises in Nairobi, Kenya. International Journal of Social Sciences and Entrepreneurship 1: 1-30.

28. Okeke MI, Okechukwu E (2014) Challenges Facing Entrepreneurs in Nigeria Singaporean Journal of Business Economics and Management Studies 3: 18-34.

29. Zeleke W (2009) Efficiency in management as a determinant of long-term survival in micro, small and medium enterprises in Ethiopia. Problems and Perspectives in Management 7: 76-84. 